\title{
Hubungan Karakteristik Peternak dengan Skala Kepemilikan Sapi Perah di Kecamatan Kabawetan Kabupaten Kepahiang
}

\author{
Irwan Nurdiyansah ${ }^{1}$, Dadang Suherman ${ }^{1 *}$ dan Heri Dwi Putranto ${ }^{1}$ \\ ${ }^{1}$ Jurusan Peternakan, Fakultas Pertanian, Universitas Bengkulu JI. WR. Supratman Kel. Kandang Limun \\ Kec. Muara Bangkahulu Bengkulu 38371A \\ .*Penulis korespondensi: dadangsuherman707@yahoo.com
}

Artikel ini diterima (received): 25 November 2020; dinyatakan disetujui (accepted): 29 November 2020; terbit (published): 27 November 2020. Artikel ini dipublikasi secara daring pada https://ejournal.unib.ac.id/index.php/buletin pt/index

\begin{abstract}
Abstrak
Penelitian ini bertujuan untuk mengetahui karakteristik peternak dan menganalisis hubungan antara karakteristik peternak dengan skala kepemilikan sapi perah di Kecamatan Kabawetan Kabupaten Kepahiang. Penelitian dilaksanakan di Kecamatan Kabawetan Kabupaten Kepahiang pada tanggal 5 Juni sampai 31 Juli 2017. Materi yang digunakan dalam penelitian adalah peternak sapi perah sebanyak 15 responden. Tahapan Penelitian dilakukan Survey terlebih dahulu untuk menentukan lokasi penelitian, surat izin penelitian dibuat oleh Fakultas Pertanian dan kemudian surat izin dikeluarkan oleh Kantor Pelayanan Perizinan Terpadu Provinsi Bengkulu, dan pengambilan data yang digunakan dalam penelitian ini berupa data primer dan data sekunder. Variabel yang diamati meliputi umur, pendidikan, lama pengalaman beternak, jumlah tanggungan keluarga, luas lahan dan kepemilikan. Data yang diperoleh dianalisis secara deskriptif berupa tabel. Analisa data yang digunakan statistik regresi linear berganda. Hasil penelitian ini adalah luas lahan berpengaruh terhadap kepemilikan ternak sapi perah, semakin luas lahan hijauan pakan ternak maka semakin meningkatkan kepemilikan ternak sapi perah, sebaliknya makin sempit lahan pertanian maka semakin rendah kepemilikan ternak sapi perah. Simpulan dari penelitian ini adalah dapat disimpulkan bahwa antara kepemilikan ternak sapi perah dengan faktor umur, pendidikan, lama pengalaman beternak, jumlah tanggungan keluarga dan luas lahan diperoleh persamaan regresi $Y=-4,091+0,029 X_{1}+0,196 X_{2}-0,395 X_{3}+0,105 X_{4}+$ $1,251 X_{5}{ }^{*}$.
\end{abstract}

Kata kunci: Karakteristik Peternak, Kecamatan Kabawetan Kabupaten Kepahiang, Sapi Perah, Skala Kepemilikan..

\section{Pendahuluan}

Pembangunan peternakan merupakan salah satu aspek yang sangat penting dalam pembangunan pertanian. Oleh karena itu, peningkatan pembangunan peternakan harus dilakukan secara terus menerus, sehingga dapat meningkatkan kesejahteraan petani peternak. Usaha peternakan sapi perah merupakan salah satu usaha peternakan yang berperan dalam perekonomian masyarakat pedesaan. Susu merupakan salah satu produk pangan hewani yang sangat diperlukan untuk kehidupan manusia, selain daging dan telur. Usaha kepemilikan ternak sapi perah di Indonesia didominasi usaha skala kecil dan menengah, dengan kepemilikan masing-masing kurang dari 4 ekor sebanyak $80 \%, 4-7$ ekor mencapai $17 \%$, dan lebih dari 7 ekor sebanyak 3\%. Rata-rata kepemilikan sapi perah sebanyak $3-5$ ekor per peternak, sehingga tingkat efisiensi usaha masih rendah (Mandaka dan Hutagaol, 2005; Maulidin, 2009).

Usaha kepemilikan sapi perah di Indonesia mempunyai prospek yang sangat besar, karena permintaan produk dari susu terus meningkat, seiring dengan pertambahan penduduk dan 
perkembangan perekonomian nasional. Namun demikian, dalam beberapa dasawarsa terakhir, impor produksi susu cenderung terus meningkat. Berdasarkan kondisi tersebut, usaha sapi perah untuk menghasilkan susu segar sangat prospektif (Sudono, 1999). Kebutuhan susu olahan di Indonesia sebesar 11,8 liter/kapital/tahun, tetapi baru dipenuhi dari dalam negeri sekitar $21 \%$ dan sisanya sebesar 79\% harus diimpor dari luar negeri (Kementerian Pertanian, 2016).

Keberhasilan usaha merupakan pencapaian target dari kerja keras peternak. Peternak sapi perah dapat dikatakan berhasil dalam menjalankan usahanya bila kompetensi yang dimilikinya bertambah, menjalankan etika usaha yang tidak merugikan orang lain, dan dapat meningkatkan produktivitas dalam usaha ternaknya (Nugraha, 2015).

Karakteristik peternak sebagai pengelola sangat menentukan tingkat keberhasilan suatu usaha peternakan. Untuk mengetahui kemampuan peternak perlu ditelusuri latar belakang yang berhubungan dengan keterlibatan dalam mengusahakan ternaknya. Sebagai pertimbangan yang digunakan untuk mengetahui kemampuan dalam mengelola ternak sapi perah meliputi umur, pengalaman peternak, tingkat kepemilikan, dan pekerjaan utama (Sundari dan Katamso, 2010).

Wahid (2012), menyatakan bahwa umur 15-64 tahun dinamakan usia produktif. Saediman (2012) bahwa tingkat produktifitas kerja seseorang akan mengalami peningkatan sesuai dengan pertambahan umur, kemudian akan menurun kembali menjelang usia tua.

Tingkat pendidikan masyarakat petani ternak sangat penting, karena dengan tingkat pendidikan dapat berpengaruh terhadap kemampuan berfikir seseorang, dalam artian mengembangkan dan meningkatkan taraf hidup melalui kreatifitas berfikir dan melihat setiap peluang serta menciptakan suatu lapangan pekerjaan (Sari, 2014).

Pengalaman beternak akan mempengaruhi terhadap kemampuan peternak dalam menjalankan usaha. Peternak yang mempunyai pengalaman yang lebih banyak akan selalu hati-hati dalam bertindak dengan adanya pengalaman buruk dimasa lalu (Iskandar dan Arfa'i, 2007).
Jumlah anggota keluarga akan
mempengaruhi keputusan petani dalam berusaha. Keluarga yang memiliki sebidang lahan tetap saja jumlahnya semakin sempit dengan bertambahnya anggota keluarga, sementara kebutuhan akan produksi terutama pangan semakin bertambah (Daniel, 2002). Rahayu (1986) menyebutkan bahwa dalam peternakan sapi perah, lahan dibutuhkan terutama untuk penyediaan Hijauan Makanan Ternak (HMT). Ketersediaan lahan secara tidak langsung mempengaruhi hubungan dengan penampilan produksi sapi perah melalui hijauan pakan yang dihasilkan.

Kabupaten Kepahiang merupakan salah satu dari dua Kabupaten yang dijadikan sebagai sentra peternakan sapi perah di Provinsi Bengkulu selain Kabupaten Rejang Lebong. Hal ini di dukung dengan keadaan wilayah Kecamatan Kabawetan Kabupaten Kepahiang yang berada di ketinggian $600-1.200$ mdpl. Pada tahun 2014 populasi sapi perah di kecamatan Kabawetan sebanyak 27 ekor serta tahun 2015 populasi sapi perah sebanyak 25 ekor (BPS Kepahiang, 2016).

Berdasarkan hal tersebut maka peneliti tertarik untuk melakukan penelitian mengenai hubungan karakteristik peternak dengan skala kepemilikan sapi perah di Kecamatan Kabawetan Kabupaten Kepahiang. Tujuan penelitian ini untuk menganalisis hubungan antara karakteristik peternak dengan kepemilikan sapi perah di Kecamatan Kabawetan Kabupaten Kepahiang.

\section{Bahan dan Metode}

Penelitian ini telah dilaksanakan di Kecamatan Kabawetan Kabupaten Kepahiang pada tanggal 5 Juni sampai 31 Juli 2017. Alat yang digunakan berupa alat tulis, kamera dan kuisioner berisi daftar pertanyaan. Materi yang digunakan dalam penelitian adalah peternak sapi perah di Kecamatan Kabawetan Kabupaten Kepahiang sebanyak 15 responden. Tahapan Penelitian dilakukan survey terlebih dahulu untuk menentukan lokasi penelitian, surat izin penelitian dibuat oleh Fakultas Pertanian dan kemudian surat izin dikeluarkan oleh Kantor Pelayanan Perizinan Terpadu Provinsi Bengkulu, dan pengambilan data yang digunakan dalam 
penelitian ini berupa data primer dan data $\quad \mathrm{X} 5 \quad=$ Luas lahan ( $\mathrm{Ha})$

Tabel 1. Karakteristik peternak berdasarkan umur, pendidikan, lama pengalaman beternak, jumlah tanggungan keluarga, luas lahan dan kepemilikan ternak di Kecamatan Kabawetan Kabupaten Kepahiang.

\begin{tabular}{lccc}
\hline Uraian Identitas & & Jumlah (Orang) & Persentase (\%) \\
\hline Umur (Tahun) & $21-30$ & 3 & 20 \\
& $31-40$ & 1 & 6.7 \\
& $41-50$ & 8 & 53.3 \\
& $51-60$ & 3 & 20 \\
\hline Pendidikan & SD & & 26.7 \\
& SLTP & 4 & 20 \\
SLTA & 3 & 40 \\
S1 & 6 & 13,3 \\
\hline Lama pengalaman beternak (tahun) & 2 & 93,3 \\
$1-3$ & & 0 \\
$4-6$ & 14 & 6,7 \\
\hline Jumlah tanggungan keluarga (Orang) & 0 & 13,3 \\
$1-2$ & 1 & 73,3 \\
$3-4$ & 2 & 6,7 \\
& $5-6$ & 11 & 6,7 \\
\hline
\end{tabular}

Sumber : Data primer yang telah diolah (2017)

sekunder. Variabel yang diamati meliputi umur, pendidikan, lama pengalaman beternak, jumlah tanggungan keluarga, luas lahan dan kepemilikan.

Data yang diperoleh dianalisis dengan menggunakan analisis regresi linear berganda. Analisa data yang digunakan untuk mengetahui hubungan antara umur, pendidikan, pengalaman beternak, jumlah tanggungan keluarga dan luas lahan dengan skala kepemilikan ternak sapi perah secara statistik regresi linear berganda (Sugiyono, 2005) dengan rumus:

$Y=a+b 1 X 1+b 2 X 2+b 3 \times 3+b 4 X 4+b 5 X 5$

Keterangan :

$\mathrm{Y} \quad=$ Jumlah kepemilikan sapi perah (UT)

$\mathrm{a}=$ adalah koefisien Intercept (konstanta)

$\mathrm{X} 1=$ Umur peternak (tahun)

X2 = Pendidikan peternak (tahun)

X3 = Lama pengalaman beternak (tahun)

X4 = Jumlah anggota keluarga (jiwa) b1 b2 b3 b4 b5 = Koefisien regresi

Uji t digunakan untuk menguji signifikan pengaruh masing-masing independent variable (Gujarati, 1999).

a. Jika t hitung $>\mathrm{t}$ tabel maka Ho ditolak dan $\mathrm{Ha}$ diterima, artinya berpengaruh.

Jika t hitung < t tabel maka Ho diterima dan $\mathrm{Ha}$ ditolak, artinya tidak berpengaruh.

\section{HASIL DAN PEMBAHASAN}

Kondisi Umum Lokasi Penelitian

Kecamatan Kabawetan terletak di sebelah utara dari Ibukota Kabupaten Kepahiang, wilayah kecamatan ini didominasi areal perbukitan yang berada pada ketinggian kurang lebih 600-1.200 meter diatas permukaan laut (dpl). Suhu $16-20^{\circ} \mathrm{C}$ pada siang hari dan kelembaban udara rata - rata $>80 \%$. Luas Wilayah Kecamatan Kabawetan lebih kurang 6.331 Hektar atau 9,52\% dari luas Kabupaten Kepahiang. Sebagaian besar kawasan 
Kecamatan Kabawetan bertopografi lereng perbukitan dan wilayah Kecamatan ini didominasi oleh areal perbukitan teh. Batas wilayah Kecamatan Kabawetan sebelah utara Kabupaten Rejang Lebong, sebelah selatan Kecamatan Kepahiang dan Kecamatan Tabat Karai, sebelah timur Kecamatan Muara Kemumu, dan sebelah barat Kecamatan Ujan Mas (BPS Kepahiang, 2016).

\section{Karakteristik Peternak}

Peternakan sapi perah yang ada di Kecamatan Kabawetan Kabupaten Kepahiang sebanyak 15 peternak. Untuk mengetahui lebih jelasnya tentang karakteristik peternak dapat dilihat pada Tabel 1.

\section{Umur}

Umur responden merupakan salah satu indikator kemampuan fisik seseorang. Seseorang yang memilki umur lebih muda cenderung akan memiliki kemampuan fisik lebih kuat dari pada umur yang lebih tua. Umur peternak dapat mempengaruhi produktifitas seseorang karena erat kaitannya dengan kemampuan kerja dan pola pikir dalam menentukan bentuk serta pola manajemen yang diterapkan dalam usaha.

Umur peternak sapi perah di Kecamatan Kabawetan Kabupaten Kepahiang memiliki perbedaan umum yang beragam dengan peternak yang paling muda berumur 24 tahun dan paling tua berumur 60 tahun. Peternak sapi perah di Kecamatan Kabawetan Kabupaten Kepahiang pada kelompok yang paling rendah umur 31-40 tahun berjumlah 1 orang peternak dengan persentase $6,7 \%$ dan kelompok yang paling tinggi umur 41-50 tahun berjumlah 8 orang peternak dengan persentase $53,3 \%$. Berdasarkan umur, maka peternak tersebut sangat berpotensi mengembangkan usaha ternak sapi perah. Hal ini sesuai dengan pendapat Hernanto (1996) yang menyatakan bahwa usia produktif sangat penting bagi pelaksanaan usaha karena usia ini peternak mampu mengkoordinasi dan mengambil langkah yang efektif.

Faktor umur seseorang ikut menentukan tingkat partisipasi kerjanya dalam mencari nafkah. Makin bertambah usia seseorang makin bertambah pula partisipasinya tetapi akan menurun pula pada usia tertentu sejalan dengan faktor kekuatan fisik yang makin menurun pula. Faktor usia akan sangat berpengaruh pada pekerjaan yang sangat mengandalkan kekuatan dan kemampuan fisik tenaga kerja. Umur akan sangat mempengaruhi produktivitas kerja karena lebih dominan mengandalkan kekuatan fisik (Akmal, 2006).

\section{Pendidikan}

Pendidikan seseorang merupakan indikator yang mencerminkan kemampuan untuk dapat menyelesaikan suatu jenis pekerjaan dan tanggung jawab. Pendidikan dibutuhkan dalam menjalankan suatu usaha tidak terkecuali dalam menjalankan usaha ternak. Pendidikan yang memadai dapat membantu masyarakat dalam upaya peningkatan produksi ternak dan kemampuan manejemen usaha peternakan.

Berdasarkan Tabel 1 menunjukkan bahwa tingkat pendidikan peternak sapi perah di Kecamatan Kabawetan Kabupaten Kepahiang lulusan paling sedikit S1 13,3\% berjumlah 2 orang peternak dan terbanyak lulusan SLTA 40\% berjumlah 6 orang peternak. Dapat diketahui bahwa sebagian peternak di Kecamatan Kabawetan Kabupaten Kepahiang sudah menyadari akan pentingnya pendidikan. Tinggi rendahnya tingkat pendidikan yang dimiliki oleh responden berpengaruh terhadap tingkat kemampuan dan cara berfikir yang dimilikinya. $\mathrm{Hal}$ ini sesuai dengan pendapat Lestraningsih dan Basuki (2008), menyatakan bahwa tingkat pendidikan berpengaruh terhadap kemampuan peternak dalam penerapan teknologi. Apabila pendidikan rendah maka daya pikirnya sempit sehingga kemampuan menalarkan suatu inovasi akan terbatas, yang akhirnya wawasan untuk maju lebih rendah dibanding dengan peternak berpendidikan tinggi.

\section{Lama pengalaman beternak}

Pengalaman beternak merupakan lama waktu yang telah dilalui peternak dalam menjalankan suatu usaha. Semakin lama pengalaman yang dimilki peternak maka akan bijak dalam mengambil keputusan. Pengalaman beternak akan diperoleh seseorang berdasarkan lama bergelut dalam suatu usaha peternakan. Pengalaman beternak merupakan faktor penting yang harus dimiliki peternak untuk memutuskan 
segala kebijakan yang akan diterapkan dalam usahanya.

Berdasarkan pada Tabel 1 menunjukkan bahwa keadaan responden di Kecamatan Kabawetan Kabupaten Kepahiang, pengalaman beternak paling sedikit pada rentang waktu 7-9 tahun dengan persentase $6,7 \%$ berjumlah 1 orang peternak dan terbanyak pada rentang waktu 1-3 tahun dengan persentase 93,3\% berjumlah 14 orang peternak. Semakin lama pengalaman beternak seseorang maka semakin banyak pula pengetahuan yang diketahui peternak untuk mendorong perkembangan usaha peternakan. Mastuti dan Hidayat (2008) menyatakan bahwa semakin lama beternak diharapkan pengetahuan yang didapat semakin banyak, sehingga keterampilan dalam menjalankan usaha peternakan semakin meningkat.

\section{Jumlah tanggungan keluarga}

Jumlah tanggungan keluarga merupakan banyaknya anggota keluarga yang dimiliki peternak sapi perah. Anggota keluarga yang dimiliki dapat memberikan dampak positif dalam usaha pemeliharaan ternak karena, anggota keluarga yang dimiliki dapat digunakan sebagai tenaga kerja.

Berdasarkan pada Tabel 1 menunjukkan bahwa jumlah tanggungan keluarga responden di Kecamatan Kabawetan Kabupaten Kepahiang terendah 5-6 orang dengan persentase 6,7\% berjumlah 1 orang peternak dan 7-8 orang dengan persentase $6,7 \%$ berjumlah 1 orang peternak sedangkan yang tertinggi 3-4 orang dengan persentase sebesar 73,3\% berjumlah 11 orang peternak. Banyaknya jumlah tanggungan keluarga dapat mempengaruhi peternak dalam menjalani usaha peternakannya. Jumlah tanggungan keluarga juga dapat membantu peternak dalam hal tenaga kerja, sebab jika anggota keluarganya banyak maka semakin ringan peternak dalam melakukan usaha peternakan karena dibantu dengan tenaga kerja keluarga. Menurut Sumbayak (2006) yang mengatakan jumlah anggota keluarga akan mempengaruhi peternak dalam pengembangan usaha. Semakin banyak jumlah tanggungan keluarga maka semakin banyak pula beban hidup yang harus dipikul seorang peternak.

\section{Luas lahan}

Luas lahan merupakan jumlah lahan usaha yang dimiliki peternak sapi perah. Berdasarkan pada Tabel 1 menunjukkan bahwa peternak sapi perah yang terendah 5-6 ha dengan persentase $6,6 \%$ berjumlah 1 orang peternak sedangkan yang memiliki luas lahan tertinggi 1-2 ha dengan persentase $46,7 \%$ berjumlah 7 orang peternak dan 3-4 ha dengan persentase $46,7 \%$ berjumlah 7 orang peternak. Banyaknya jumlah lahan dapat mempengaruhi peternak dalam menjalani usaha ternaknya. Luas lahan juga dapat membantu peternak dalam menanam hijauan pakan dan membuat kandang usaha ternaknya. Sebagaimana yang dikemukakan Sudono et al. (2003), menyatakan lahan merupakan faktor penting dalam upaya pengembangan peternakan sapi, karena lahan dalam peternakan dapat digunakan untuk membangun kandang dan menanam rumput sebagai penyedia hijauan. Keberadaan lahan untuk penanaman rumput mutlak diperlukan.

\section{Kepemilikan Ternak Sapi Perah}

Kepemilikan sapi perah yang ada di Kecamatan Kabawetan Kabupaten Kepahiang sebanyak 34 ekor ternak sapi perah. Untuk mengetahui lebih jelasnya tentang kepemilikan dan jumlah periode sapi perah dapat dilihat pada Tabel 2.

Tab el 2. Kepemilikan dan periode ternak sapi perah di Kecamatan Kabawetan Kabupaten Kepahiang

\begin{tabular}{ccc}
\hline $\begin{array}{c}\text { Umur Ternak } \\
\text { Sapi Perah }\end{array}$ & $\begin{array}{c}\text { Jumlah (Unit } \\
\text { Ternak) }\end{array}$ & $\begin{array}{c}\text { Persentase } \\
(\mathbf{\%})\end{array}$ \\
\hline Pedet & 2,31 & 8,27 \\
Dara & 2,64 & 9,44 \\
Induk & 23 & 82,29 \\
\hline Kepemilikan & Jumlah & Persentase \\
Sapi Perah & (Orang) & $\mathbf{( \% )}$ \\
(Unit Ternak) & & \\
\hline $1-2$ & 14 & 93,3 \\
$3-4$ & 0 & 0 \\
$5-6$ & 1 & 6,7 \\
\hline
\end{tabular}

Sumber : Data primer (2017)

Berdasarkan pada Tabel 2 menunjukkan bahwa jumlah periode sapi perah di Kecamatan Kabawetan Kabupaten Kepahiang yang paling rendah kepemilikan pedet 2,31 (UT) dengan 
persentase $8,27 \%$ dan yang paling tinggi $Y=-4,091+0,029 X_{1}+0,196 X_{2}-0,395 X_{3}+$

Tabel 3. Hasil analisis regresi linier berganda hubungan karakteristik peternak dengan skala kepemilikan sapi perah

\begin{tabular}{lccc}
\hline \multicolumn{1}{c}{ Variabel Bebas } & Koefisien Regresi & $\mathrm{T}_{\text {}}$ Kitung & \\
\hline Constant & $-4,091$ & & \\
Umur $\left(\mathrm{X}_{1}\right)$ & 0,029 & 0,922 & $\mathrm{NE}$ \\
Pendidikan $\left(\mathrm{X}_{2}\right)$ & 0,196 & 1,774 & $\mathrm{NE}$ \\
Lama Pengalaman Beternak $\left(\mathrm{X}_{3}\right)$ & $-0,395$ & $-1,673$ & $\mathrm{NE}$ \\
Jumlah Tanggungan Keluarga $\left(\mathrm{X}_{4}\right)$ & 0,105 & 0,480 & $\mathrm{NE}$ \\
Luas Lahan $\left(\mathrm{X}_{5}\right)$ & 1,251 & 4,501 & \\
\hline $\mathrm{R}$ & 0,887 & & \\
$\mathrm{R}^{2}$ & 0,769 & & \\
$\mathrm{t}$-tabel $(5 \%: 2=2,5 \%),(\mathrm{df}) \mathrm{n}-\mathrm{k}-1=9$ & 2,262 & & \\
\hline
\end{tabular}

Sumber : Data primer yang telah diolah (2017)

kepemilikan indukan 23 (UT) dengan persentase $82,29 \%$. Tabel 2 menunjukkan bahwa jumlah kepemilikan ternak sapi perah responden di Kecamatan Kabawetan Kabupaten Kepahiang masih berskala sedang. Hal ini terlihat dari 93,3\% responden yang memiliki 1-2 UT sapi perah. Hal ini sesuai pendapat Rasali et al. (2013) yang menyatakan bahwa lebih dari $90 \%$ berupa peternakan rakyat yang memiliki ciri skala usaha relatif kecil berkisar antara 1-5 ekor. Besar atau kecil jumlah kepemilikan ternak yang dimiliki oleh peternak sangatlah membantu dalam meningkatkan pendapatan dan pemenuhan kebutuhan. Hal ini sejalan dengan pendapat Paturochman (2005) yang menyatakan bahwa besar kecilnya kepemilikan ternak sangat mempengaruhi tingkat pendapatan, jadi makin tinggi kepemilikan ternak maka makin besar tingkat pendapatan peternak.

\section{Hubungan Karakteristik Peternak Dengan Skala Kepemilikan Sapi Perah}

Hasil analisis regresi linier berganda digunakan untuk mengetahui pengaruh variabel independen $(\mathrm{X})$ terhadap variabel dependen $(\mathrm{Y})$. Variabel independen dalam penelitian meliputi umur peternak $\left(X_{1}\right)$, pendidikan $\left(X_{2}\right)$, pengalaman beternak $\left(X_{3}\right)$, jumlah tanggungan keluarga $\left(X_{4}\right)$, dan luas lahan $\left(X_{5}\right)$ dapat dilihat pada Tabel 3.

Berdasarkan hasil analisis regresi linier berganda yang tertera pada Tabel 3 menunjukkan bahwa antara kepemilikan ternak sapi perah dengan faktor umur, pendidikan, lama pengalaman beternak, jumlah tanggungan keluarga dan luas lahan diperoleh persamaan regresi sebagai berikut:
$0,105 X_{4}+1,251 X_{5}^{*}$

Berdasarkan persamaan tersebut, masingmasing variabel dapat digambarkan pengaruhnya terhadap kepemilikan ternak sapi perah di Kecamatan Kabawetan Kabupaten Kepahiang.

Korelasi Ganda (R) berdasarkan tabel 3 diperoleh angka $R$ sebesar 0,877. Hal ini menunjukkan bahwa terjadi hubungan yang sangat kuat antara umur, pendidikan, pengalaman beternak, tanggungan keluarga dan luas lahan terhadap kepemilikan.

Koefisien determinasi $\left(R^{2}\right)$ berdasarkan tabel 3 diperoleh angka $R$ Square $\left(R^{2}\right)$ 0,769 atau $76,9 \%$ menunjukkan bahwa $76,9 \%$ kepemilikan ternak sapi perah dipengaruhi oleh variabel dalam model, sedangkan sisanya sebesar $23,1 \%$ dipengaruhi oleh variabel lain yang tidak dimasukkan dalam model penelitian ini.

Berdasarkan uji t dapat dinyatakan bahwa diduga variabel bebas umur $\left(X_{1}\right)$, Pendidikan $\left(X_{2}\right)$, lama pengalaman $\left(X_{3}\right)$, jumlah tanggungan keluarga $\left(X_{4}\right)$, dan luas lahan $\left(X_{5}\right)$ dapat mempengaruhi kepemilikan ternak sapi perah (Y).

\section{Variabel Umur $\left(X_{1}\right)$}

$\operatorname{Umur}\left(X_{1}\right)$ mempunyai pengaruh positif terhadap kepemilikan ternak sapi perah, tetapi berdasarkan uji $t$ tidak berpengaruh terhadap kepemilikan ternak sapi perah $(\mathrm{Y})$, karena nilai $t_{\text {hitung }}$ sebesar 0,922 dengan $t_{\text {tabel }}$ 2,262 maka $t_{\text {hitung }}$ lebih kecil dari $t_{\text {tabel }}(0,922<2,262)$. Dapat disimpulkan bahwa umur tidak ada hubungannya dengan kepemilikan ternak sapi perah. Hal tersebut umur peternak berada pada usia produktif tetapi lebih mencurahkan waktunya pada usaha taninya. Makatita (2013) 
yang menyatakan bahwa umur peternak tidak berpengaruh dengan skala usaha, karena peternak yang berusia produktif lebih memperhatikan usaha taninya dibanding usaha peternakan. Hal ini ditambahkan oleh Romjali et al. (2012) yang menyatakan bahwa pada umumnya usaha ternak hanya usaha sampingan yang dipelihara sebagai tabungan (investasi) yang dapat dijual kapan saja.

\section{Variabel Pendidikan $\left(\mathrm{X}_{\mathbf{2}}\right)$}

Pendidikan $\left(X_{2}\right)$ mempunyai pengaruh positif terhadap kepemilikan ternak sapi perah, tetapi berdasarkan uji $\mathrm{t}$ tidak berpengaruh terhadap kepemilikan ternak sapi perah $(\mathrm{Y})$, karena nilai $t_{\text {hitung }}$ sebesar 1,774 dengan $t_{\text {tabel }}$ 2,262 , maka $t_{\text {hitung }}$ lebih kecil dari $t_{\text {tabel }}(1,774<$ 2,262), sehingga dapat disimpulkan bahwa pendidikan tidak berpengaruh terhadap kepemilikan ternak sapi perah. Hal ini disebabkan pendidikan responden relatif sama, sehingga menunjukkan tidak ada hubungannya dengan kepemilikan ternak sapi perah berdasarkan pendidikan. Peternak yang mempunyai tingkat pendidikan rendah, kepemilikan ternak sapi perah relatif sama dengan peternak yang mempunyai tingkat pendidikan yang tinggi. Hal ini disebabkan tingkat pendidikan yang dimiliki peternak bersifat umum, karena pendidikan yang didapatkan dari SD sampai SMA yang tidak spesifik pada bidang peternakan. Hal ini sesuai dengan pendapat Soekartawi (1988) menyatakan bahwa dalam prakteknya hubungan antara tingkat pendidikan dan tingkat adopsi pertanian adalah berjalan secara tidak langsung, kecuali bagi peternak yang belajar secara spesifik tentang inovasi tersebut di sekolah.

Tinggi rendahnya pendidikan yang dimiliki oleh peternak tidak menjamin bahwa mereka akan mengembangkan usahanya, sebab tidak ada perbedaan antara jumlah kepemilikan ternak dilihat dari segi pendidikan. Hal ini tidak sesuai dengan pendapat Murwanto (2008) bahwa tingkat pendidikan yang memadai akan berdampak pada peningkatan kinerja dan kemampuan manajemen usaha peternakan yang dijalankan.

\section{Variabel Lama Pengalaman Beternak $\left(\mathbf{X}_{3}\right)$}

Lama pengalaman beternak $\left(X_{3}\right)$ memberi pengaruh negatif terhadap kepemilikan ternak sapi perah dan memperoleh nilai thitung sebesar 1,673 dengan $t_{\text {tabel }} 2,262$, maka $t_{\text {hitung }}$ lebih kecil dari $t_{\text {tabel }}(-1,673<2,262)$. Berdasarkan hal tersebut dapat disimpulkan bahwa lama pengalaman beternak tidak berpengaruh terhadap kepemilikan ternak sapi perah. Lama pengalaman beternak relatif sama dengan peternak yang mempunyai lama pengalaman 2 tahun dengan lama pengalaman yang 7 tahun, sehingga lama pengalaman tidak ada hubungannya dengan kepemilikan ternak sapi perah berdasarkan lama pengalaman beternak. Lama pengalaman tidak berpengaruh dengan kepemilikan sapi perah dikarnakan peternak tidak untuk memajukan usaha selanjutnya. Hal ini tidak sesuai dengan pendapat Atmadilaga (1995) bahwa semakin lama beternak maka peternak akan semakin berpengalaman dan mereka dapat belajar dari pengalaman yang pernah dialaminya untuk memajukan usaha selanjutnya. Ditambahkan oleh Febriana dan Liana (2008) bahwa pengalaman beternak yang cukup lama memberikan indikasi bahwa pengetahuan dan keterampilan peternak terhadap manajemen pemeliharaan ternak mempunyai kemampuan yang lebih baik. Pengalaman beternak sangat berpengaruh terhadap keberhasilan usaha. Semakin lama seseorang memiliki pengelaman beternak akan semakin mudah peternak mengatasi kesulitankesulitan yang dialaminya.

\section{Variabel Jumlah Tanggungan Keluarga $\left(\mathbf{X}_{4}\right)$}

Jumlah tanggungan keluarga $\left(\mathrm{X}_{4}\right)$ mempunyai pengaruh positif terhadap kepemilikan ternak sapi perah. Berdasarkan hasil uji $t$ tidak berpengaruh terhadap kepemilikan ternak sapi perah $(\mathrm{Y})$, karena nilai thitung sebesar 0,480 dengan $t_{\text {tabel }} 2,262$, maka $t_{\text {hitung }}$ lebih kecil dari $t_{\text {tabel }}(0,480<2,262)$. Hal tersebut dapat disimpulkan bahwa jumlah tanggungan keluarga tidak berpengaruh terhadap kepemilikan ternak sapi perah. Berdasarkan hal tersebut, bahwa antara peternak yang mempunyai tanggungan keluarga 1 orang, maka skala kepemilikan sapi perah relatif sama dengan peternak yang mempunyai tanggungan keluarga 7 orang. Hasil yang didapatkan dari beternak sapi perah tidak digunakan untuk membeli induk ataupun bibit, 
tetapi digunakan untuk menutupi kebutuhan keluarga. Hal ini sesuai dengan pendapat Lestari et al. (2009) bahwa peternak yang mempunyai tanggungan keluarga yang besar akan mempunyai beban ekonomi yang besar pula untuk memenuhi kebutuhan hidup keluarganya.

Banyaknya tanggungan keluarga tidak memberikan dorongan positif terhadap peningkatan pendapatan peternak. Hal ini tidak sesuai dengan pendapat Sumbayak (2006) yang mengatakan bahwa jumlah anggota keluarga akan mempengaruhi peternak dalam pengembangan usaha. Karena semakin banyak jumlah tanggungan keluarga maka semakin banyak pula beban hidup yang harus dipikul oleh seorang peternak.

\section{Variabel Luas Lahan $\left(X_{5}\right)$}

Luas lahan $\left(X_{5}\right)$ mempunyai pengaruh positif terhadap kepemilikan ternak sapi perah dan memperoleh nilai $t_{\text {hitung }}$ sebesar 4,501 dengan $t_{\text {tabel }} 2,262$, maka $t_{\text {hitung }}$ lebih besar dari $t_{\text {tabel }}(4,501>2,262)$. Hal ini dapat disimpulkan bahwa luas lahan berpengaruh terhadap kepemilikan ternak sapi perah, semakin luas lahan hijauan pakan ternak maka semakin meningkatkan kepemilikan ternak sapi perah, sebaliknya makin sempit lahan pertanian maka semakin rendah kepemilikan ternak sapi perah. Hal tersebut menunjukkan bahwa luas lahan akan mempengaruhi ketersediaan hijauan pakan yang mengakibatkan kepemilikan ternak semakin meningkat. Hal ini sesuai pendapat Wahyuni (2013) semakin banyak lahan seseorang, semakin banyak pula jumlah ternak yang dipelihara. Dengan kepemilikan lahan yang cukup, seorang peternak akan merasa aman dalam hal penyediaan hijauan ternak setiap hari karena dapat memperoleh hijauan yang berkualitas dengan menanam rumput. Hal ini ditambahkan oleh Sudono et al. (2003), menyatakan lahan merupakan faktor penting dalam upaya pengembangan peternakan sapi perah, karena lahan dalam peternakan dapat digunakan untuk membangun kandang dan menanam rumput sebagai penyedia hijauan, keberadaan lahan untuk penanaman rumput mutlak diperlukan.

\section{Kesimpulan}

Berdasarkan hasil penelitian dan pembahasan dapat disimpulkan bahwa antara kepemilikan ternak sapi perah dengan faktor umur, pendidikan, lama pengalaman beternak, jumlah tanggungan keluarga dan luas lahan diperoleh persamaan regresi.

$Y=-4,091+0,029 X_{1}+0,196 X_{2}-0,395 X_{3}+$ $0,105 X_{4}+1,251 X_{5}$

Hasil analisis regresi linier berganda faktor umur (X1), pendidikan (X2), lama pengalaman (X3), dan tanggungan keluarga (X4) tidak berpengaruh terhadap kepemilikan sapi perah (Y), sementara faktor luas lahan (X5) memberikan kontribusi berpengaruh terhadap kepemilikan ternak sapi perah (Y)..

\section{Daftar Pustaka}

Akmal, Y. 2006. Analisis Faktor-Faktor Yang Mempengaruhi Produktivitas Tenaga Kerja Industri Kecil Kerupuk Sanjai Di Kota Bukittinggi. Institut Pertanian Bogor. Bogor.

Atmadilaga. 1985. Modernisasi Peternakan Ditinjau dari Segi Potensi dan Masalah Gizi. Kadin Jawa Barat, Bandung.

BPS Kepahiang. 2016. Kecamatan Kabawetan dalam Angka 2016. Kepahiang

Daniel, M. 2002. Pengantar Ekonomi Pertanian. Bumi Aksara, Jakarta.

Febrina, D dan M. Liana. 2008. Pemanfaatan Limbah Pertanian Sebagai Pakan Ruminansia Pada Peternak Rakyat Di Kecamatan Rengat Barat Kabupaten Indragiri Hulu. Jurnal Peternakan. 5(1) : 2837

Gujarati. D. 1999. Basic Econometric. PT Erlangga. Jakarta.

Hernanto, F. 1996. Ilmu Usaha Tani. Penebaran Swadaya. Jakarta.

Iskandar, I dan Arfa'i 2007. Analisis Program Pengembangan Usaha Sapi Potong Di Kabupaten Lima Puluh Kota, Sumatera Barat (studi kasus program bantuan pinjaman langsung masyarakat). Skripsi. Fakultas Peternakan Universitas Andalas. Padang.

Kementerian Pertanian. 2016. Pusat Data dan Sistem Informasi Pertanian dalam Angka 2016. Jakarta.

Lestari, W., S. Hadi dan N. Idris. 2009. Tingkat Adopsi Inovasi Peternak dalam Beternak Ayam Broiler di Kecamatan Bajubang Kabupaten Batang Hari. Jurnal IImiah IImuIlmu Peternakan. 12(1) : 14-22 
Lestraningsih, M dan Basuki, E. 2008. Peran Serta Wanita Peternak Sapi Perah Dalam Meningkatkan Taraf Hidup Keluarga. Jurnal Ekuitas. 12(1) : 121-141

Makatita, J. 2013. Hubungan Antara Karakteristik Peternak Dengan Skala Usaha Pada Usaha Peternakan Kambing Di Kecamatan Leihitu Kabupaten Maluku Tengah. Jurnal Agrinimal. 3(2) : 78-83

Mandaka, S., dan M.P. Hutagaol. 2005. Analisis Fungsi Keuntungan, Efisiensi Ekonomi dan Kemungkinan Skema Kredit Bagi Pengembangan Skala Usaha Peternakan Sapi Perah Rakyat. J. Agro Eko. 23(2) : 191208.

Mastuti dan Hidayat. 2008. Peranan Tenaga Kerja Wanita dalam Usaha Ternak Sapi Perah di Kabupaten Banyumas (Role of Women Workers at Dairy Farms in Banyumas District). Jurnal Animal Production. 11(1) : 40-47

Maulidin,A.M. 2009. Motivasi Peternak Dalam Kegiatan Berusaha Ternak Domba Di Desa Rencamayar Kecamatan Baleendah Kabupaten Bandung. Skripsi Fakultas Peternakan. Universitas Padjadjaran. Bandung.

Murwanto, A.G. 2008. Karakteristik Peternak dan Tingkat Masukan Teknologi Peternakan Sapi Potong di Lembah Prafi Kabupaten Manokwari. Jurnal Ilmu Peternakan. 3(1) : 8 $-15$.

Nugraha AS. 2015. Motivasi Berprestasi Peternakan Sapi Perah Dalam Mencapai Keberhasilan Usaha. Skripsi. Fakultas Peternakan Universitas Padjadjaran. Bandung

Paturochman, M. 2005. Hubungan Antara Tingkat Pendapatan Keluarga Peternak Dengan Tingkat Konsumsi (Kasus di Koperasi Peternakan Bandung Selatan (KPBS) Pangalengan). Skripsi. Fakultas Peternakan Universitas Padjadjaran, Bandung

Rahayu, S. 1986. Analisis usahaternak sapiperah dalam suatu sistem usahatani (Studi Kasus di Kecamatan Lembang, Kabupaten
Bandung). Tesis. Sekolah Pasca Sarjana. Institut Pertanian Bogor. Bogor

Rasali, H., Matondang dan S.Rusdiana. 2013. Langkah-Langkah Strategis dalam Mencapai Swasembada Daging Sapi/Kerbau 2014. Pusat Penelitian dan Pengembangan Peternakan Depertemen Pertanian. Bogor

Romjali, E., Edwardi. dan S. Rusdiana. 2012. Peluang Dan Potensi Usaha Ternak Kerbau di Sumatera Barat. Lokakarya nasional Perbibitan Kerbau

Saediman. 2012. Pengaruh Skala Usaha terhadap Pendapatan Peternak Ayam Ras Petelur Di Kec, Maritengngae Kab. Sidrap. Skripsi Fakultas Peternakan. Universitas Hasanuddin. Makassar.

Sari, A.I. 2014. Analisis Keuntungan Peternakan Ayam Ras Petelur Di Kecamatan Mattiro Bulu Kabupaten Pinrang. Skripsi Fakultas Peternakan. Universitas Hasanuddin. Makassar.

Soekartawi. 1988. Prinsip Dasar Komunikasi Pertanian. Universitas Indonesia Press. Jakarta

Sudono, A. 1999. Ilmu Produksi Ternak Perah. Diktat Kuliah Fakultas Peternakan Institut Pertanian Bogor. Bogor.

Sudono, A. Rosdiana dan B. S. Setiawan. 2003. Beternak Sapi Perah Secara Intensif. Agromedia Pustaka. Bogor.

Sugiyono. 2005. Statistika Untuk Penelitian. Penerbit CV Alfabeta, Bandung.

Sumbayak, J.B. 2006. Materi, Metode, dan Media Penyuluhan. Fakultas Pertanian. Universitas Sumatera Utara. Medan.

Sundari dan Katamso. 2010. Analisis Pendapatan Peternak Sapi Perah Lokal dan Eks-impor Anggota Koperasi Warga Mulya Di Kabupaten Sleman Yogyakarta. Jurnal Caraka Tani. 25(1) : 26-32

Wahid S. 2012. Faktor-Faktor Pertumbuhan Penduduk. http://rakangeografi. blogspot. com. Diakses pada Maret 2017.

Wahyuni R. 2013. Struktur penguasaan Sumber Daya Lahan dan KontribusiUsaha Ternak Sapi Potong Terhadap Pendapatan Rumah Tangga Petani. Jurnal Widyariset. 18(1) : 79-9 